\title{
LANGUAGE, COGNITION AND STYLE: AN INTRODUCTION TO THE COGNITIVE STYLISTICS SECTION
}

\author{
Carmen M. Bretones Callejas, Susana Ridao Rodrigo \\ and Salvador Alarcón Hermosilla, University of Almería, Spain \\ Emails: cbreton@ual.es, sridao@ual.es, s.alarcon.hermosilla@gmail.com
}

\begin{abstract}
This is an introduction to Cognitive Stylistics, broadly defined as the study of style from a cognitive perspective. Stylistics deals not only with the analysis of the internal linguistic features of a given linguistic proposition or a stretch of discourse, but also what lies outside the text, namely, author, sociocultural context, genre, and so on. It is founded on the main assumption that the function and meaning of a text can be interpreted in the light of its formal aspects, thus engaging with formal description and its relation to a given situation and a given cognitive context.

Keywords: Cognitive Science, Cognitive Linguistics, Cognitive Poetics, Cognitive Stylistics, conceptual structure.

Resumen: Esta es una introducción a la Estilística Cognitiva, definida de manera general como el estudio del estilo desde una perspectiva cognitiva. La estilística se ocupa no solo del análisis de las características lingüísticas internas de una proposición lingüística determinada o de un tramo de discurso, sino también de lo que se encuentra fuera del texto, es decir, el autor, el contexto sociocultural, el género, etc. Se basa en el supuesto principal de que la función y el significado de un texto pueden interpretarse a la luz de sus aspectos formales, comprometiéndose así en la descripción formal y su relación con una situación y un contexto cognitivo determinados.

Palabras clave: Ciencia Cognitiva, Lingüística Cognitiva, Poética Cognitiva, Estilística Cognitiva, Estructura Conceptual.
\end{abstract}

Cognitive Linguistics (CL) is a field of investigation in Cognitive Science that conceives language as an integrated phenomenon within general human cognitive abilities. One of the CL deep roots departs form Noam Chomsky's Syntactic Structures (1957) and from Montegue's Universal Grammar (1970). Chomsky's language theory claimed that human linguistic faculty was of a mainly syntactic nature, and that the essence of language lies in the human capacity to combine a series of finite elements, the words, in such a way that they are able to express an infinite number of linguistic messages. Further on, it was noticed that we also need the semantics of a linguistic item that can be conceived as the objective conditions under which it may truthfully be stated, while the syntax was the mathematical structure of its linguistic elements and relations irrespective of their semantics. This view 
overlooked certain aspects of language which have proved to constitute essential to the study of language; aspects of a cultural, psychological, social, or stylistic nature. But by the mid 1970s, cognitivist pioneers such as George Lakoff, Charles Fillmore, Ronald Langacker, Leonard Talmy or Eleonor Rosch, started fresh lines of investigation, and although it is difficult to say when CL was really born, it has been widely acknowledged that Lakoff and Johnson's book Metaphors we live by (1980), marks the beginning of what we know today as CL, with central developments such as conceptual domain, conceptual metaphor, and conceptual metonymy.

One of the most relevant assumptions of $\mathrm{CL}$ is to consider language as a human general instrument to help us understand the world (Bretones 2001, 2005, Barsalou 2008, Gallese and Lakoff 2005, Tomasello 2008). For example, since our brain cannot filter all of the perceptual information it receives, we use strategies such as the segregation of the information between figure and background. This cognitive process has been labelled as profiling by Langacker, or windows of attention by Talmy and make understanding possible. Specific sensorial experiences such as color, are experienced differently by speakers of different languages. For example, speakers of Russian and speakers of English (Boroditsky 2000, 2011), or speakers of Argentinian Spanish and Peninsular Spanish (Bretones \& Solís 2011) understand 'blue' differently. Each language requires from its speakers the arrangement of mental structure in connection to their language, arrangement that can even shape basic mechanisms like our visual system.

Within the scope of CL, several schools of thought have arisen over the years. Ronald Langacker developed Cognitive Grammar (CG), in which the linguistic structure is reduced to patterns of neurological activity, and put forward the notion of entrenchment. Authors like Fillmore, Goldberg or Butler, among many others, elaborated different trends of thought under the umbrella term of Construction Grammar (CG), whereby the dichotomy between lexis and grammar is blurred and melts into sets of intermediate levels. Charles Fillmore is the most prominent figure of Frame Semantics, which claims that in order to characterize in a suitable way the meanings of linguistic elements, we must first know the underlying conceptual structures on which they are based. Gilles Fauconnier and Mark Turner developed the Mental Spaces Theory and the Conceptual Integration Theory, or what is best known as Blending. These theories defend the view that mental spaces, although linguisticallymotivated, do not have a linguistic nature, but reflect more general cognitive operations. An expression may evoke various distinct mental spaces, which are, nevertheless, inherently coherent with each other. Comprehension occurs when the evoked entities are connected via a process of projection, or mapping, giving rise to what Fauconnier and Turner termed blended spaces, defined as emergent expressions which often contain elements that pertain to none of the mental spaces. Cognitive Poetics conceive cognition as the study of the mental processes involved in the craft of literature (Freeman 2012, Stockwell 2019, Chamizo \& Bretones 2005) and Cultural Cognition sees language as a social and semiotic institution (Lucy 1992, Sinha 2009, 2015).

Within the vast field of CL, mention should be made to the scope of investigation known as Cognitive Stylistics, broadly defined as the study of style from a cognitive perspective. Stylistics deals not only with the analysis of the internal linguistic features of a given linguistic proposition or a stretch of discourse, but also what lies outside the text, namely, 
author, sociocultural context, genre, and so on. It is founded on the main assumption that the function and meaning of a text can be interpreted in the light of its formal aspects, thus engaging with formal description and its relation to a given situation in space and time, a given cognitive context (Simpson 2004, McIntyre 2008, Jeffries 2010, Montini 2017).

The present volume section includes some invaluable contributions by a series of remarkable scholars with assorted and fresh views of CL in general, and Stylistics in particular. This section is done in memory of Charles Fillmore, Giles Faucconier, and Per Aage Brandt, and in commemoration of the 20th Anniversary of September 11, 2001.

Craig Hamilton contributes a startling approach to La Prose du Transsibérien et de la petite Jeanne de France by Blaise Cendrars in the light of Conceptual Integration Theory. La Prose du Transsibérien et de la petite Jeanne de France is an unusual work of modern art that has posed many problems in literary criticism for many years, and Hamilton makes it accessible and shows that reading this complex work entails a number of conceptual blends, such as the FORM IS CONTENT integration. Daban Qasim Jaff et al. discuss the metaphorical representation of trauma stress in Jewell Parker Rhodes' Towers Falling (2016). The study adopts insights from the conceptual metaphor theory (CMT) by George Lakoff and Mark Johnson (1980) as a model of analysis on selected metaphors from the novel, such as EMOTION IS PRESSURE INSIDE A CONTAINER, THE BODY IS A CONTAINER FOR EMOTION, and TRAUMA IS A CONTAINER. Taiwo Oloruntoba-Oju examines how the cognitive stylistic model of analysis can be useful in the interpretation of African skits, revealing how viewers make interpretive connections between the text-world and the real world. Elena del Carmen Martínez López delves into the connection between language and literature with specific reference to Jane Austen's Pride and Prejudice, in the light of the principles and taxonomies of Brown and Levinson's Politeness Theory. Coral Calvo Maturana explores adoption and foster care discourse (AFD) so as to uncover the role of multimodal novel metaphor, illustrating the cognitive power of multimodal creative choices in relation to (AFD) to integrate children's past, present, and future experiences.

All in all, this section of Odisea aims at contributing to the growing field of Cognitive Linguistics and Stylistics. A section like this one has never been arranged before in this journal, and it hopefully will not — should not— be the last time.

\section{REFERENCES}

Barsalou, L. 2008. “Grounded Cognition.” Annual Review Psychology, 59: 617-645.

Boroditsky, L. 2000. "Metaphoric Structuring: Understanding Time through Spatial Metaphors.” Cognition, 75: 1-28.

Boroditsky, L. 2011. “How Language Shapes Thought.” Scientific American, 304,2: 62-65.

Bretones Callejas, C. M. 2001. "Synaesthetic Metaphors in English.” ICSI Technical Reports. http://www. icsi. berkeley. edu/ftp/pub/techreports/2001/tr-01-008. pdf

Bretones Callejas, C. M. 2003. "Entrevista a Charles J. Fillmore.” ODISEA. Revista de estudios ingleses, 4: 41-48. 
Bretones Callejas, C. M. 2005. "What's your Definition of Synesthesia: A Matter of Language or Thought." In Proceedings of the Annual Meeting of the Cognitive Science Society.

Bretones Callejas, C. M. \& Solís Sáez, S. 2011. "Linguistic Variation, Culture and Cognition: Compartive Analysis of Peninsular vs. Argentinian Spanish.” In Eugenio Coseriu, lingüista entre dos siglos. Madrid: Iberoamericana Editorial Vervuert.

Domínguez, P. \& Bretones Callejas, C. M. 2005. "Euphemisms, Proverbs, Allusions, and Cognition: A Study of Two Poems by Antonio Machado." Círculo de lingüística aplicada a la comunicación, 22.

Chomsky, N. 1981. Lectures on Government and Binding. Dordrecht: Foris.

Chomsky, N. 2009 [1957]. Syntactic Structures. Berlin: Mouton de Gruyter.

Fillmore, C. J. 1975. "An alternative to checklist theories of meaning." Proceedings of the Berkeley Linguistics Society, 1: 123-131.

Fillmore, C. J. 2008. "Frame semantics.” In Cognitive Linguistics: Basic Readings. De Gruyter Mouton, 373-400.

FreEman, M. H. 2012. "Poetry and the scope of metaphor: Toward a cognitive theory of literature". In Metaphor and Metonymy at the Crossroads: A Cognitive Perspective. Antonio Barcelona Ed. Berlin: Mouton de Gruyter. 253-282.

Goldberg, A. 1995. Construction Grammar. Chicago: University of Chicago Press.

GALLESE, V. \& LAKOFF, G. 2005. “The brain's concepts: the role of the sensory-motor system in reason and language." Cognitive Neuropsychology, 22: 455-479.

Jefrereys, L. 2010. Critical Stylistics. The Power of English. Basingstoke, Palgrave MacMillan.

LAKOFF, G. \& JoHnson, M. 1980. Metaphors we live by. Chicago: University of Chicago Press.

Lakoff, G. \& Johnson, M. 1999. Philosophy in the Flesh: The Embodied Mind and Its Challenge to Western Thought. New York: Basic Books.

Lakoff, G. \& Turner, M. 1989. More than Cool Reason: A Field Guide to Poetic Metaphor. Chicago: Chicago University Press.

LANGaCKer, R.W. 1987. Foundations of Cognitive Grammar. Vol 1 \& 2. Stanford: Stanford University Press.

LuCY, J. 1992. Grammatical Categories and Cognition: A Case Study of the Linguistic Relativity Hypothesis (Studies in the Social and Cultural Foundations of Language). Cambridge: Cambridge University Press.

Mcintyre, D. 2008. "Integrating Multimodal Analysis and the Stylistics of Drama: A Multimodal Perspective on Ian McKellen's Richard III." Language and Literature, 17,4: 309-344.

Montague, R. 1970. “Universal Grammar.” Theoria, 36: 373-398. 
MontinI, D. 2017. "Preface. Stylistics Reloaded: Tradition and Prospects of an Impure Discipline. Fictions." Studi sulla narratività, XVI: 9-20.

Rosch, E. 1978. Principles of Categorization. Cognition and Categorization. Hillsdale, NJ: Lawrence Erlbaum. 27-48.

SINHA, C. 2009. "Language as a biocultural niche and social institution." In New Directions in Cognitive Linguistics. Amsterdam: John Benjamins, 289-310.

SinHA, C. 2015. "Language and other artifacts: Socio-cultural dynamics of niche construction." Frontiers in Psychology. 6: 1601. DOI: 10.3389/fpsyg.2015.01601.

Stockwell, P. 2019. Cognitive Poetics: An Introduction. London: Routledge.

Talmy, L. 2000. Toward a Cognitive Semantics. Vol 1 \& 2. Cambridge, MA: MIT Press.

Tomasello, M. 2008. The Origins of Human Communication. Cambridge, MA: MIT Press. 